\title{
DINAMIKA PENYUSUNAN QANUN ACEH (STUDI KASUS DI BADAN LEGISLASI DEWAN PERWAKILAN RAKYAT ACEH)
}

\author{
DYNAMICS OF LEGAL DRAFTING IN ACEH \\ (CASE STUDIES ON COUNCIL LEGISLATION BOARD)
}

\author{
Tasmiati Emsa ${ }^{1}$, Afrizal Tjoetra ${ }^{2}$ Ikhsan $^{3}$ \\ Fakultas Ilmu Sosial dan Ilmu Politik, Universitas Iskandar Muda ${ }^{1}$ \\ Fakultas Ilmu Sosial dan Ilmu Politik, Universitas Teuku Umar ${ }^{23}$ \\ miaemsa@yahoo.com, afrizaltjoetra@utu.ac.id, ikhsan.baharudin@utu.ac.id
}

\begin{abstract}
Abstrak
Penelitian ini membahas tentang dinamika penyusunan qanun di Dewan Perwakilan Rakyat Aceh. Qanun merupakan komitmen pemangku kekuasaan di daerah yang memiliki kekuatan untuk mewujudkan masyarakat yang diinginkan (social engineering) dan kehidupan sosial dalam masyarakat Pada penelitian ini, penulis menggunakan pendekatan kualitatif, dengan pertimbangan penulis bermaksud memperoleh gambaran dinamika dalam Pembentukan Qanun, lokasi penelitian pada Dewan Perwakilan Rakyat Aceh. Untuk memperoleh sumber data dalam penelitian ini dibagi menjadi 2 (dua) bagian yaitu melalui pemilihan informan dilakukan dengan pertimbangan secara sengaja (purposive sampling). Berdasarkan pada jenis dan sumber data yang diperlukan, teknik pengumpulan data yang digunakan meliputi (a) Wawancara mendalam, (b) Analisis Dokumentasi, dan (c) Observasi Langsung. Teknik analisis data menggunakan model interaktif yang meliputi tiga komponen analisis, yaitu reduksi data, penyajian data, penarikan kesimpulan dinamika dalam penyusunan sebuah qanun. Hasil penelitian ini menunjukkan bahwa dalam penyusunan sebuah qanun proses pengakomodasian kepentingan para pihak dan kemampuan anggota DPRA dalam bidang legal drafting sangat menentukan kualitas dan kuantitas.
\end{abstract}

Kata Kunci: Dinamika, Penyusunan, Qanun, Badan Legislasi

\begin{abstract}
Village Village funds budgeted by the Central Government for West Aceh District increase every year by 84.3 billion (2015) and 249 billion (2019). However, the implementation cannot be used optimally. This paper discusses the existence of village clinics as a solution to the many delays and mistakes in managing village funds in Aceh. The gampong clinic is a village government capacity building program through training and guidance, coordination, consultation and information sharing, especially in terms of planning and budgeting for village funds. This research method uses qualitative methods with a descriptive approach. The informants of this study were the sub-district government, village government and the community. The results showed that the village gampong program was effective in assisting the
\end{abstract}


management of village funds in Aceh by increasing the capacity of the village government, assisting in developing development plans, making financial accountability reports, and assisting the community empowerment process by fielding village assistants who were prepared to help solve village problems such as poverty and unemployment.

Keywords: dynamics, Legal Drafting, Qanun, Council Legeslation Board

\section{Pendahuluan}

Salah satu alat kelengkapan DPRA yang bersifat tetap dan dibentuk oleh dewan pada awal masa jabatan adalah Badan Legislasi (Baleg). dengan tugas diantaranya menyusun program legislasi dan merancang qanun inisiatif DPRA berdasarkan program prioritas yang sudah ditetapkan setiap tahun. Program legislasi yang telah direncanakan oleh Baleg pada dalam melahirkan sebuah produk Qanun, masih lamban dalam menghasilkan Qanun-Qanun yang sudah dimasukkan dalam Program legislasi. Terhitung sejak tahun 2010, jumlah realisasi pengesahan Qanun jika dibandingkan dengan jumlah yang jumlah Qanun yang masuk menjadi Program legislasi sangat jomplang.

Anggota Baleg yang aktif memberikan masukan pada saat pembahasan Qanun hanya 1/3 (satu per tiga) dari anggota Komisi. Pembuatan Qanun langsung masuk pada perumusan pasal-pasal, jarang sekali Dewan, Pemerintah Daerah dan masyarakat berupaya untuk memehami konteks dan substansi tentang suatu hal yang akan diatur dalam Qanun. Bahkan naskah akademik dibuat belakangan. Idealnya naskah akademik menjadi bahan acuan yang penting bagi DPR Aceh maupun Pemerintah Daerah.

Baleg menghasilkan qanun yang yang kurang berkualitas sehingga kurang memberikan manfaat langsung kepada masyarakat hal ini disebabkan oleh proses dan perencanaan masih bermasalah. Proses perencanaan dan koordinasi masih ada beberapa masalah dalam Prolega, kualitas Qanun yang dihasilkan belum memadai sehingga kurang memberikan manfaat langsung bagi kehidupan masyarakat. Lemahnya tingkat koordinasi diantara alat kelengkapan DPRA dalam menyusun dan pembahasan suatu Rancangan Qanun. Kurangnya koordinasi ini misalnya, ditandai oleh munculnya secara tiba-tiba satu Rancangan Qanun yang tidak pernah ada didalam dalam daftar prioritas. Tujuan dari penelitian ini adalah untuk melihat dinamika dalam menghasilkan sebuah qanun yang dirancang oleh badan legislasi (Baleg) sehingga bisa dipetakan faktor penentu dalam pembentukan sebuah qanun.

\section{Metode Penelitian}

Penelitian ini menggunakan metode kualitatif untuk mengetahui terhadap gambaran dinamika Badan Legislasi pada Dewan Perwakilan Rakyat Aceh dalam pembuatan 
Qanun. Alasan penggunaan pendekatan kualitatif dapat dijelaskan bahwa suatu pendekatan yang dilakukan secara persuasif kepada informan-informan yang diperlukan oleh peneliti agar mendapatkan informasi dalam suatu penyelesaian penelitian. Fokus penelitian ini adalah pada dinamika Badan Legislasi dan factor yang mempengaruhi dalam pembuatan sebuah qanun.

Data penelitian ini didapat dari observasi dan wawancara mendalam bersama dengan narasumber penelitian sebagai data primer. Sedangkan data sekunder diperoleh melalui pembacaan terhadap buku, jurnal, media massa dan dokumen tertulis lainnya. Data yang diperoleh kemudian dianalisis dengan cara reduksi data dan penarikan kesimpulan.

\section{Hasil dan Pembahasan}

\section{Dinamika Penyusunan Qanun}

Berdasarkan Undang-Undang Pemerintah Aceh Nomor 11 Tahun 2006 itulah nama lembaga yang sebelumnya disebut Dewan Perwakilan Rakyat Daerah (DPRD) Provinsi Aceh diubah menjadi Dewan Perwakilan Rakyat Aceh (DPRA) yang menghilangkan sebutan "daerah" bagi nama DPRD tingkat Provinsi Aceh memang hanya berlaku khusus untuk Aceh berdasarkan Undang-undang Negara Republik Indonesia Nomor 11 Tahun 2006. Sementara untuk Provinsi-provinsi lain di Indonesia masih disebut Dewan Perwakilan Rakyat Daerah Provinsi, atau DPRD Provinsi.

Kedudukan, tugas dan fungsi Dewan sebagaimana termaktub dalam Undang-undang Pemerintah Aceh Nomor 11 Tahun 2006, pasal 22 Bab VII, Bagian Kesatu, secara umum adalah menjalankan fungsi legislasi, anggaran dan pengawasan. Dalam pasal 2 ayat 1 sampai 5 dijelaskan bahwa DPR Aceh merupakan lembaga Perwakilan Rakyat Aceh yang berkedudukan sebagai unsur penyelenggara Pemerintahan Aceh (ayat 1). Ayat 2 menyatakan DPR Aceh merupakan wadah untuk melaksanakan musyawarah/mupakat berdasarkan demoktrasi Pancasila dan Undang-Undang Dasar Republik Indonesia Tahun 1945, dan Undang-Undang Nomor 11 Tahun 2006 tentang Pemerintahan Aceh yang berlandaskan MoU Helsinki 15 Agustus 2006.

Badan legislasi merupakan alat kelengkapan DPR Aceh yang bersifat tetap dan dibentuk oleh DPR Aceh pada awal masa jabatan anggota DPR Aceh yang beranggotakan 19 (sembilan belas) orang. Anggota Badan Legislasi ini terdiri dari berbagai Fraksi DPR Aceh yang dibagi berdasarkan azas perimbangan yang proporsional. Penempatan anggota DPR Aceh dalam Badan Legislasi didasarkan atas usul Fraksinya yang berkedudukan sebagai pusat perencanaan pembentukan qanun dan apabila membutuhkan tambahan anggota dalam pembahasan rancangan qanun-qanun, Badan Legislasi dapat meminta tambahan anggota dari fraksi-fraksi melalui Pimpinan Dewan. 
Sebagai lembaga Pemerintahan Aceh, DPR Aceh mempunyai kedudukan setara dan memiliki hubungan kerja bersifat kemitraan dengan Pemerintah Aceh. Kedudukan yang setara bermakna bahwa antara DPR Aceh dan Pemerintah Aceh memiliki kedudukan yang sama dan sejajar dalam arti tidak saling membawahi. Hubungan bersifat kemitraan berarti DPR Aceh merupakan mitra kerja Pemerintah Aceh dalam membuat kebijakan daerah untuk melaksanakan kekhususan Aceh sesuai dengan tugas dan fungsi masing-masing. Maka untuk terjalinnya hubungan kerja yang harmonis dan saling mendukung diperlukan adanya pengaturan terkait fungsi dan tugasnya masing-masing. Prinsip hubungan kemitraan antara anggota Dewan Perwakilan Rakyat Aceh dengan Gubernur Aceh tergambar dari masing-masing tugas yang telah disebutkan dalam Undang-Undang Nomor 11 Tahun 2006 tentang Pemerintahan Aceh.

Koordinasi antara DPR Aceh dan Pemerintah Aceh dilakukan melalui penyusunan Program Legislasi Aceh secara bersama-sama yang dibuat pada awal periode tahunan sesuai dengan kebutuhan riil. Dalam proses kesepakatan untuk membuat Program Legislasi Aceh itu DPR Aceh dan Pemerintah Aceh bersama-sama mengajukan daftar rancangan Qanun yang diperlukan untuk kemudian dipilih dan/atau diintegrasikan guna dijadikan kesepakatan antar keduanya. Kesepakatan ini tentang Program Legislasi Aceh, baik yang untuk 5 (lima) tahun maupun yang untuk perioritas tahunan yang dituangkan kedalam keputusan DPR Aceh.

Mekanisme pembentukan Program legislasi Aceh dimulai dari perencanaan baik di lingkungan pemerintah maupun di lingkungan DPRA. Badan Legislasi mengkoordinasikan pada lingkungan DRP Aceh dan juga masyarakat. Hasil koordinasi tersebut lahir konsepsi dari DPR Aceh. Kemudian Banleg dan Biro Hukum melakukan koordinasi untuk mensikronisasi masing-masing konsepsi dan memunculkan Program Legislasi bersama. Kemudian Biro Hukum pemerintah meminta persetujuan kepala pemerintahan (Gubernur) untuk persetujuan. Setelah mendapat persetujuan dengan mekanisme internal di pemerintahan, maka draft bersama tersebut disahkan melalui rapat paripurna DPRA dan melahirkan Surat Keputusan DPR Aceh.

Badan Legislasi (Banleg) Dewan Perwakilan Rakyat Aceh (DPRA) bersama jajaran eksekutif menetapkan 69 (enam puluh Sembilan) rancangan qanun (Raqan) menjadi Program Legislasi Aceh (prolega) yang akan dibahas pada masa keanggotaan DPRA periode 2014-2019. Untuk Tahun 2015 Badan legislasi juga menetapkan 16 rancangan qanun prioritas yang akan dibahas.

Untuk menghasilkan sebuah produk Qanun yang baik dan sesuai dengan tuntutan kebutuhan masyarakat, maka perlu dilakukan berdasarkan prosedur penyusunan Qanun agar lebih terarah dan terkoordinasi. Dalam pembuatan Qanun perlu adanya persiapan- 
persiapan yang matang dan mendalam, antara lain: dimilikinya pengetahuan mengenai materi muatan yang akan diatur dalam Qanun; Adanya pengetahuan tentang bagaimana menuangkan materi muatan tersebut kedalam rancangan Qanun secara singkat tetapi jelas, dengan pilihan bahasa yang baik dan mudah dipahami.

Berdasarkan temuan lapangan menunjukan bahwa selama masa periode tahun 2014 2015 DPR Aceh memiliki 14 (empat belas) keputusan yang mengatur tentang koordinasi DPR Aceh dengan Eksekutif tentang koordinasi dalam pembahasan Rancangan Qanun.

Rancangan yang berasal dari anggota Dewan, sekurang-kurangnya diajukan oleh 5 orang anggota sebagai pemrakarsa yang berasal dari 2 (dua) fraksi atau lebih. Pemrakarsa melaporkan rencana penyusunan pra prancangan qanun aceh kepada pimpinan DPRA disertai dengan penjelasan selengkapnya mengenai konsepsi pengaturan rancangan qanun yang meliputi latar belakang dan tujuan penyusunan, dasar hokum, sasaran yang ingin diwujudkan, pokok pikiran, lingkup atau objek yang akan diatur, jangkauan serta arah pengaturan dan, keterkaitan dengan perundang-undangan.

Qanun dibentuk berdasarkan asas pembentukan peraturan perundang-undangan yang meliputi kejelasan tujuan, kelembagaan atau organ pembentukan yang tepat, kesesuaian antara jenis dan materi muatan. Selanjutnya, materi muatan Qanun mengandung asas pengayoman, kemanusiaan, kebangsaan, kekeluargaan, keanekaragaman, keadilan, nondiskriminasi, kebersamaan kedudukan dalam hukum, dan/ atau keseimbangan, keserasian, kesetaraan, dan keselarasan pasal 237 (ayat 1). Pada aspek materi qanun, diharapkan mampu memuat materi yang responsif terhadap kepentingan rakyat, melindungi hak asasi manusia dan memuat nilai-nilai keadian. Di samping itu materi Qanun perlu disusun dengan menganut asas-asas pengayoman, kemanusiaan, kebangsaan, kekeluargaan, kareateristik, keanekaragaman, keadilan, non diskriminasi, kesamaan kedudukan dalam hukum dan pemerintahan, ketertiban dan kepastian hukum serta keseimbangan, keserasian, kesertaan dan keselarasan.

Pembahasan rancangan Qanun di DPRA dilakukan oleh DPRA bersama kepala Daerah (Gubernur). Dalam tahap pembahasan rancangan Qanun masyarakat dapat dilibatkan, partisipasi publik dapat dibuka dengan mekanisme Rapat Dengar Pendapat Umum (RDPU) maupun melalui penyampaian aspirasi terbuka. Di pihak masyarakat baik kalangan akademisi maupun praktisi dapat memberikan masukan subtansi terhadap rancangan Qanun. RDPU ini dilaksanakan di Kabupaten/Kota, karena Qanun ini nantinya berlaku untuk seluruh kabupaten/Kota di Aceh.

Pada Tahun 2014, ada 12 (dua belas) Rancangan Qanun Aceh yang dimasukan program legislasi Aceh, terdiri 4 (empat) Qanun usul inisiatif DPRA dan 8 (delapan) Rancangan Qanun prakarsa Gubernur/eksekutif. Sampai Agustus 2014 belum ada satupun 
realisasi program legislasi tersebut. namun sebelum berakhirnya DPRA periode tahun 2014 baru disahkan 7 (tujuh) Qanun. Pada periode ini diselenggarakannya Pimilihan Presiden dan Pemilihan Umum Legislatif, adanya pencalonan anggota DPRA pada Pemilu 2014. Tingkat kehadiran dan keaktifan anggota DPRA relatif rendah. Hal ini mengakibatkan alasan terhambatnya proses pembahasan Qanun. Hal ini adanya kelalaian anggota Badan Legislatif dan kemampuan Badan Legislasi tidak professional terkesan kurang pemahaman tentang perencanaan dalam fungsi legislasi.

Pada Tahun 2015 yang menjadi Prolega ada 16 (enam belas) Qanun, namun diakhir bulan November dan Desember baru ada 3 (tiga) Qanun yang diparipurnakan. Secara sederhana, indikator keberhasilan kinerja DPRA di bidang legislasi, secara kuantitatif dapat ditentukan oleh seberapa banyak Qanun dibentuk dan diamandemen setiap tahun. Periode 2015 minimnya realisasi pembentukan Qanun Aceh dikarenakan berbagai faktor DPR Aceh.

\section{Faktor Penentu dalam Penyusunan Qanun}

Pendidikan sangat erat kaitannya dengan pengetahuan, secara tidak langsung pendidikan dapat mempengaruhi pola pikir dan prilaku anggota dewan. Masa depan yang selalu berkembang menuntut pendidikan untuk selalu menyesuaikan diri dan menjadi lokomotif dari proses demokratisasi dan peradaban bangsa. Begitu juga pentingnya pendidikan bagi anggota Dewan Perwakilan Rakyat sehingga memastikan reformasi bangsa berjalan sesuai dengan fungsinya sebagai legislatif. Apalagi persyaratan menjadi anggota DPR Aceh adalah pendidikan minimal SLTA dan atau sederajat. Karena itulah ada tuntutan dari masyarakat agar para anggota DPR Aceh mampu meningkatkan kualitasnya baik segi pendidikan dan pengalaman yang tentunya akan berdampak terhadap daya kritis menyikapi permasalahan isu publik dalam melahirkan suatu kebijakan publik.

Secara garis besar fungsi pendidikan menyiapkan generasi untuk memiliki kemampuan agar bisa memegang peranan-peranan di kehidupan bermasyarakat. Memindahkan ilmu pengetahuan yang berkaitan dengan peranan-peranan di dan Memindahkan nilai-nilai dengan tujuan agar keutuhan dan kesatuan masyarakat terpelihara, sebagai syarat utama berlangsungnya kehidupan suatu masyarakat dan juga peradaban.

Pendidikan secara tidak langsung dapat mempengaruhi pola pikir dan prilaku dalam memahami seluk beluk tugas dan fungsi legislatif. Persyaratan pendidikan menjadi anggota dewan minimal SLTA atau sederajat, sangat berdampak kepada kinerja anggota dewan. Sehingga kurangnya dukungan bahan referensi sebagai rujukan ketika ikut terlibat dalam pembahasan rancangan qanun sehingga secara kualitas dan kuantitas yang dihasilkan oleh anggota Dewan Perwakilan Rakyat belum sesuai dengan ekspektasi masyarwakat. 
Faktor selanjutnya yang menyebabkan rendanya secara kualitas dan kuantitas qanun qanun yang dihasilkan oleh dewan perwakilan rakyat aceh karena lemahnya sistem politik dan faktor individu sendiri sebagai aktor dalam politik. Dalam pendekatan behaviorisme, individualah yang dipandang secara aktual melakukan kegiatan politik, sedangkan perilaku lembaga politik pada dasarnya merupakan perilaku individu dengan pola tertentu. Oleh karena itu, untuk menjelaskan perilaku suatu lembaga yang perlu ditelaah bukan lembaganya, melainkan latar belakang individu yang secara aktual mengendalikan lembaga. Partai sebagai salah satu instrument politik yang memiliki tujuan menempatkan wakilwakilnya didalam Dewan Perwakilan Rakyat Aceh. Partai politik juga sangat diperlukan untuk menampung seluruh aspirasi rakyat dapat memperjuangkan program-program untuk kepentingan umum serta pembentukan sebuah kebijakan publik.

\section{Penutup}

Badan Legislasi menyusun program legislasi yang memuat daftar urutan rancangan qanun untuk 1 (satu) periode keanggotaan 5 (lima) tahun, menyiapkan rancangan qanun inisiatif DPRA berdasarkan program prioritas yang telah ditetapkan setiap tahun dan lima tahunan, yang bersifat inisiatif, mengolah, merencanakan dan membahas serta mengesahkan Qanun Aceh. Keterlibatan legislatif dalam perumusan kebijakan publik harus dimulai dari proses identifikasi masalah dan kebutuhan masyarakat yang perlu diprioritaskan penanganannya. Sehingga Qanun bukan sekedar naskah yang dirumuskan oleh DPR Aceh, akan tetapi merupakan kaidah-kaidah yang harus ditaati oleh semua pelaku tata pemerintahan didaerah dan masyarakatnya. Pendidikan, pengalaman dan partai politik secara instutusi menjadi penentu dalam menghasilkan qanun baik secara kualitas maupun kuantitas.

\section{Daftar Pustaka}

Djajasoekarto, Agung. (2009). Seri Buku Panduan Meningkatkan Kinerja Fungsi Legislatif DPRD: Jakarta ADEKSI.

Gibson, Ivancevich. (2009). Organisasi dan manajemen. Perilaku, struktur, proses. Edisi keempat. Jakarta: Erlangga

Moleong, Lexi. J. (2014). Metode Penelitian Kualitatif. Bandung: PT. Remaja Rosdakarya. Prasojo, Eko, dkk. (2007). Pemerintahan Daerah . Jakarta: Universitas Terbuka

Wasistiono, Sadu. (2009). Meningkatkan Kinerja Dewan Perwakilan Rakyat Daerah (DPRD). Bandung: Fokus Media . 
Zulkifli. (2011). Disertasi Konstitusi Peranan Legislatif Dalam Peranan Kebijakan Publik (Kajian Legislatif dengan Eksekutif dalam proses perumusan kebijakan, pencegahan dan pemberantasan Tindak Pidana Pencucian Uang) Universitas Padjajaran. 